\title{
Space State Matrices Based Novel PI and Sliding Mode Controllers for Step-Up Converters in Renewable Energy Applications
}

\author{
Davood Ghaderi ${ }^{*}$ \\ ${ }^{1}$ Bursa Teknk Üniversitesi, Mühendislik ve Doğa Bilimler Fakültesi, Elektrik Elektronik Mühendisliği Bölümü, Bursa, Türkiye (ORCID: 0000-0003-2234-3453)
}

(İlk Geliş Tarihi 17 Nisan 2019 ve Kabul Tarihi 8 Ağustos 2019)

(DOI: $10.31590 /$ ejosat.590831)

ATIF/REFERENCE: Ghaderi, D. (2019). Space State Based Novel PI and Sliding Mode Controllers for Step-Up Converters in Renewable Energy Applications. European Journal of Science and Technology, (16), 841-854.

\begin{abstract}
Photovoltaic panels generate a limited amount of power, so the transmission of this power to the grid side should be done by an efficient DC-DC converter structure and a powerful controller circuit. The controller should be designed based on accurate mathematical analysis to act with high quality and use the minimum number of components as much as possible in order to obtain a cheap and simple topology. In this study, the performance analysis of a novel proportional-integral (PI) controller and Sliding Mode Controller (SMC) methods for a DC-DC power boost converter is examined in Continuous Conduction Mode (CCM). Having a comprehensive mathematical model for the converter allows designing an accurate controller. So, in the first step, an exhaustive model for this converter based on steady space matrixes has been presented. In the next step, these two different controllers investigated based on the proposed model of the boost converter and finally, comparisons for the performance analysis of presented controllers have been done. One of the novelty aspects of the PI controller is that it will give sample currents of the inductor to make a relation between the output voltage and the controller strategy in order to generate suitable pulses to drive the power switch and SMC does not need to any sampling for this purpose and acts through tracking the output voltage.
\end{abstract}

Keywords: PI controller, Sliding Mode Controller, Renewable energu sources, Step-Up converter, Space state analysis.

\section{Yenilenebilir Enerji Uygulamalarında Yükseltici DA DA Dönüş̧türücüler için Uzay Durum Matrislerine Dayalı yeni PI ve Kayan Kipli Modu Kontrolörler}

\section{$\ddot{O} z$}

Bir Fotovoltaik (PV) panelin üretilen güç miktarının belli bir limitleri aşabilmemesi ve sınırlı olmasını bilmekle birlikte, yenilenebilir energy kaynaklarında verimin son derece önemli olduğu nedeniyle kontrol devresinin performansı oldukça önemlidir. Bu enerjinin aktarımı kaliteli kontrol algoritmalarına dayanarak, kayıpları en az değerlere düşürebilmek için farklı çalışmalarda dikkate alınmıştır. Bu çalışmada, DA-DA Boost dönüştürücüsü için uzay durumu matrislerini geliştirerek, yeni Orantılı İntegral (PI) ve Kayan Kipli Modu (SMC) tabanlı Kontrolör yöntemlerinin performans analizi dönüştürücünün Sürekli İletim Modunda (CCM) incelenmiştir. Dönüştürücü için kapsamlı bir matematiksel model elde etmek, doğru bir kontrol sisteminin tasarlanmasına yol açmabilmektedir. Böylece, ilk adımda, sabit uzay matrislerine dayanan matimatik modelleme yöntemleriyle, dönüştürücünün çıkış gerilimi ve giriş akımı için kapsamlı bir model sunulmuştur. Bir sonraki adımda, bu iki farklı kontrolör, sunulan modele dayanarak, araştırılmış ve son olarak, sunulan kontrolörlerin performans analizi için karşılaştırmalar yapılmıştır. Bu iki yeni modele göre, SMC metodu daha iyi sonuçlar sunmaktadır. Çalışmanın yenilik yönlerinden biri, PI kontrolörü, anahtarı tetiklemek için sürekli bobinin akımından örnekler alamkta olması, SMC yönteminde ise bu örnekleme sadece çıkış geriliminden alınmasıdır.

Anahtar Kelimeler: PI controller, Sliding Mode Controller, Renewable energu sources, Step-Up converter, Space state analysis.

\footnotetext{
${ }^{*}$ Sorumlu Yazar: Bursa Teknk Üniversitesi, Mühendislik ve Doğa Bilimler Fakültesi, Elektrik Elektronik Mühendisliği Bölümü, Bursa, Türkiye (ORCID: 0000-00032234-3453), davood.ghaderi@btu.edu.tr
} 


\section{Giriş}

With developing technology, the need for different forms of electrical energy is constantly increasing. Depending on the progress in the field of power electronics, many converters have been developed for this purpose. DC-DC converters are frequently used as power electronics converters that convert the input direct voltage to different output voltage in many industrial applications where direct voltage adjustment is needed [1-3].

DC-DC step-up are converters that convert the input direct voltage to a higher level output direct voltage [4]. As with other types of DC-DC converters, the step-down and buck-boost DC-DC converters [5,6], the correct voltage conversion in the converter depends on the PWM switching ratio. Ideally, the relationship between converter input and output voltage can be achieved mathematically, depending on the switching ratio independent of system parameters. In practice, however, non-ideal converter elements (passive elements and switching elements) and the fact that the converter operates in intermittent mode make it impossible to determine a certain switching ratio for the respective operating point of the converter [7].

In order to increase the efficiency of the power converter, suitable converters are often used in parallel or in series based on levels of the power and voltage in a transmission block. The most significant disadvantage of using the converter singly at high powers is that it is subjected to high voltage and current stress. Therefore, in high power applications, the parallel connection of two or more amplifying converters is recommended to reduce the current wavelength. This technique involves phase shifting problem of the control signal of several cells in parallel operation at the same switching frequency [4].

Interest in the problem of harmonic current contamination in Renewable Energy (RE) based systems has increased significantly in recent years especially for the Photovoltaic panels. Due to the negative effects of sinusoidal current waveform distortion, studies are carried out to reduce the harmonics of the input current. Many interface circuit studies are performed to correct the power factor (PF) of the systems. Usually, the power factor correction for DC-DC converters which actively adjust the shape of the input current to the desired form based on load values is used to correct the power factor of the power transmission side. Power factor correction transducers are an important field of study and research in power electronics to regulate the power supply output and provide an acceptable ratio of active and apparent power [8-10].

The purpose of the control systems is to ensure that the control variables for the processes follow the desired change form under changing operating conditions.

Therefore, in order to obtain the switching ratio of the converter, it is necessary to use a feedback control structure based on the reference and actual output voltages [10].

There are many studies in the literature using many different types of controllers for controlling the amplifier DC-DC converters [11-14]. The designed controller continuously checks the error between the converter reference and the actual output voltage and corrects the converter operating error to provide the desired system response parameters. The feedback control structure using classical PI and PID controller types is often applied in amplifier converter control [15-17]. In many studies, which are thought to be insufficient in terms of converter response of PI and PID controllers, the floating mode controller based control technique, which is one of the modern control techniques for the converter control, has been successfully applied [18-20]. The design of the controllers mentioned in the present literature is designed for the mathematical model obtained for certain operating points of the converter. Therefore, it is obvious that the change in any of the system operating parameters will change the mathematical model of the converter. Therefore, in this case, it is not possible to obtain the system response performance with the designed controller parameters. In terms of amplifier converter performance, it is very important that the reference output voltage value provides the desired system response performance, as well as the converter, produces the reference output voltage value accurately on the output side. It is therefore evident that the converter control structures in which said controller types are used alone cannot provide the desired converter performance, except for the operating points where the controller parameters are obtained for a given operating point.

In this study, different control methods are analyzed by using a classical single - switch DC-DC step-up type converter structure. Two different controller have been investigated in this study. An improved PI controller and a new Sliding Mode Controller based on space state matrices are the methods applied to the converter and all mathematical and simulation results are presented. For as good and qualified controller design, first of all, knowing the mathematical behavior of the converter is the main part. So, a successful control process will be possible through a wide and complete model based on converters activity in both ON and OFF states of the power switch. For that, all facts related to modeling of the step-up converter has been presented firstly and controllers investigated through the model. A comparison between the quality of the output voltage and current signals, especially when the load changes, have been done and the performance of the controllers have been reported.

\section{Mathematic analysis of the step-up converter}

A general configuration of RESs connected networks has been illustrated in figure 1. This simple figure shows that any type of sources after stabilization by a capacitor bank can be converted to a DC voltage $\mathrm{n}$ the desired level. DC grids will be supplied directly through this DC voltage and ac grids need to supply by an inverter block that can convert DC voltages to the ac ones. It is clear that the level of the voltages in the grid sides can determine that a buck or boost converter should be applied for the DC-DC converter. Since the PV panels generate a limited amount of voltage and power, normally a boost converter is applied to enhance the DC voltage level to can be used in one phase 220 or three phases 380 Vac applications. 


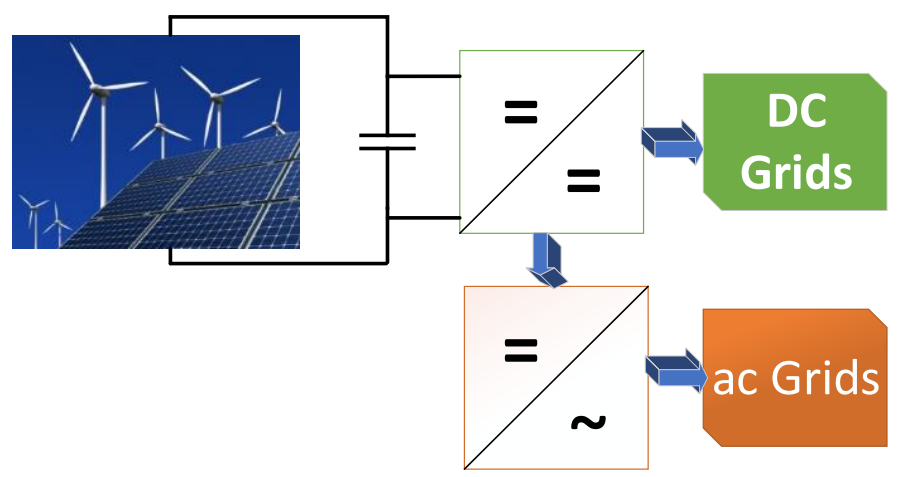

Figure 1. Power stages in a RES connected network

This section presents the steady space analysis of the boost converter when the power switch is in ON and OFF states. A conventional step-up converter has been presented in figure 2a. subfigures 2.b and 2.c presents the state of the converter when the power switch is in ON and OFF states respectively.

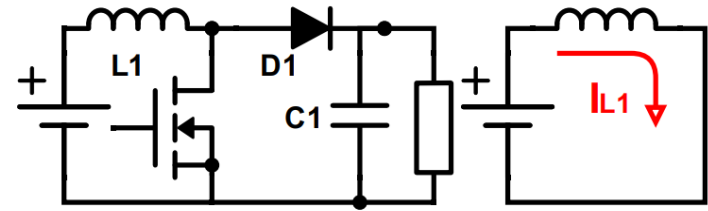

(a)

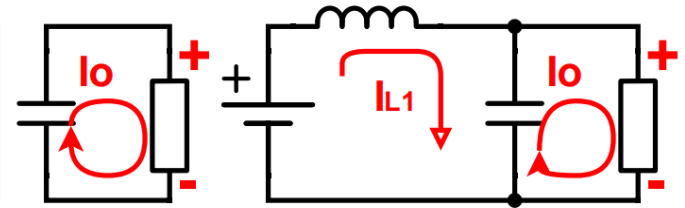

(c)

Figure 1. (a) Boost converter, the state of converter when the power switch is in (b) ON and (c) OFF modes.

Mode1: When the power switch is in ON mode, input voltage charges the inductor through the switch, in this state, the voltage on capacitor will discharge on load. So the current for the inductor will increase and the voltage on capacitors will decrease in this time interval. So we can write:

$$
\begin{aligned}
& L \frac{d i_{L}}{d t}=V_{i n} \Rightarrow \frac{d i_{L}}{d t}=\frac{V_{i n}}{L} \\
& C \frac{d v_{o}}{d t}=-\frac{v_{o}}{R} \Rightarrow \frac{d v_{o}}{d t}=-\frac{v_{o}}{C R}
\end{aligned}
$$

So the steady space matrix for the ON sate can be written by (3):

$$
\left\{\begin{array}{l}
L \frac{d i_{L}}{d t}=V_{i n} \Rightarrow \frac{d i_{L}}{d t}=\frac{V_{i n}}{L} \\
C \frac{d v_{o}}{d t}=-\frac{v_{o}}{R} \Rightarrow \frac{d v_{o}}{d t}=-\frac{v_{o}}{R C}
\end{array}\right\} \Rightarrow\left[\begin{array}{l}
\dot{i_{l 1}} \\
\dot{v_{o 1}}
\end{array}\right]=\left[\begin{array}{cc}
0 & 0 \\
0 & -\frac{1}{R C}
\end{array}\right]\left[\begin{array}{l}
i_{l} \\
v_{o}
\end{array}\right]+\left[\begin{array}{l}
\frac{1}{L_{1}} \\
0 \\
0 \\
0
\end{array}\right]\left[V_{i n}\right]
$$

Mode2: For the OFF state of power switch, as figure 2c presents, inductor will demagnetize on capacitor through the diode, so the current of inductors will decrease while the voltage of the capacitor will increase. So in this time interval, the structure will behave completely opposite with the first time interval. Inductor current, capacitor voltage and steady space matrix for this state can be obtained respectively through (4), (5) and (6):

$$
\begin{aligned}
& L \frac{d i_{L}}{d t}=\left(V_{i n}-v_{C}\right)(1-d) \Rightarrow \frac{d i_{L}}{d t}=\frac{V_{i n}-v_{C}}{L}(1-d) \\
& C \frac{d v_{o}}{d t}=\left(i_{L}-\frac{v_{o}}{R}\right)(1-d) \Rightarrow \frac{d v_{o}}{d t}=\frac{i_{L}-\frac{v_{o}}{R}}{C}(1-d)
\end{aligned}
$$




$$
\left\{\begin{array}{l}
L \frac{d i_{L}}{d t}=\left(V_{i n}-v_{C}\right)(1-d) \Rightarrow \frac{d i_{L}}{d t}=\frac{V_{i n}-v_{C}}{L}(1-d) \\
C \frac{d v_{o}}{d t}=\left(i_{L}-\frac{v_{o}}{R}\right)(1-d) \Rightarrow \frac{d v_{o}}{d t}=\frac{i_{L}-\frac{v_{o}}{R}}{C}(1-d)
\end{array}\right\} \Rightarrow\left[\begin{array}{l}
\dot{i_{l}} \\
\dot{v_{o}}
\end{array}\right]=\left[\begin{array}{cc}
0 & -\left(\frac{1-d}{L}\right) \\
\frac{1-d}{C} & -\left(\frac{1-d}{R C}\right)
\end{array}\right]\left[\begin{array}{l}
i_{l} \\
v_{o}
\end{array}\right]+\left[\begin{array}{l}
\frac{1}{L_{1}} \\
0
\end{array}\right]\left[V_{\text {in }}\right]
$$

In above equations, $d$ is the duty cycle of the signal which drives the power switch. If the switch is in ON mode for the dT, so it will be in OFF mode for the (1-d) T. In these terms, T is the period of the PWM signal. Figure 3 illustrates the components conductivity stations in per time interval.

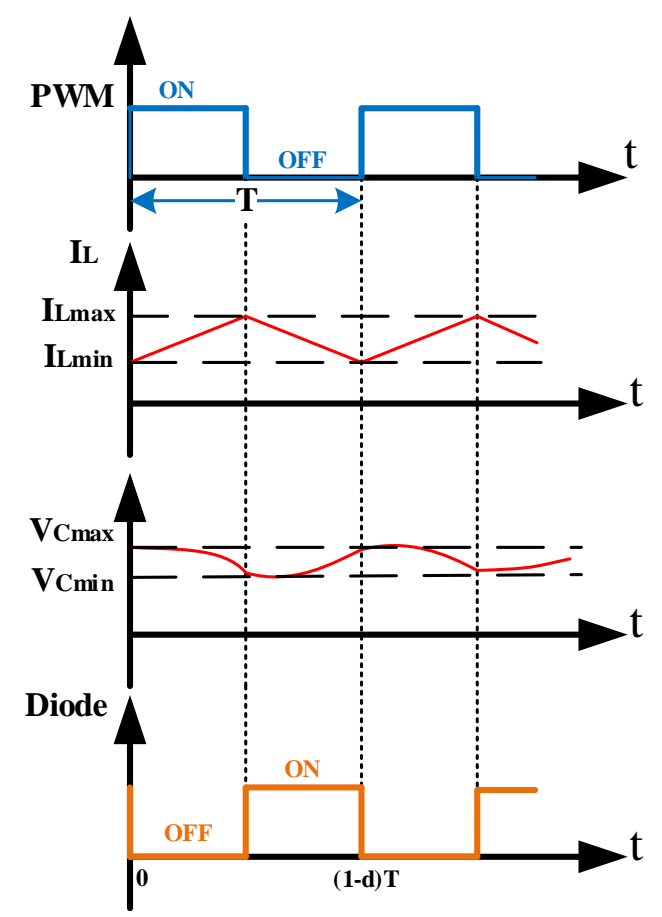

Figure 3. The state of components in a period of PWM.

By considering the equations (3) and (6), the general state matrix of the converter will be equal with:

$$
\left\{\begin{array}{l}
\frac{d i_{L}}{d t}=-\frac{(1-d)}{L} v_{C}+\frac{1}{L} V_{i n} \\
\frac{d v_{o}}{d t}=\frac{(1-d)}{C} i_{L}-\frac{1}{R C} v_{o}
\end{array}\right\} \Rightarrow\left[\begin{array}{l}
\dot{i_{l}} \\
\dot{v_{o}}
\end{array}\right]=\left[\begin{array}{cc}
0 & -\left(\frac{1-d}{L}\right) \\
\frac{1-d}{C} & -\frac{1}{R C}
\end{array}\right]\left[\begin{array}{l}
i_{l} \\
v_{o}
\end{array}\right]+\left[\begin{array}{l}
\frac{1}{L_{1}} \\
0
\end{array}\right]\left[V_{i n}\right]
$$

Equation (11) illustrates that the relation between input sources, inductors current and capacitor voltages derivatives and output voltage can be written as:

$$
Y=C X+D u
$$

In this equation $\mathrm{C}$ is the coefficient matrix, $\mathrm{X}$ is the inductor currents or capacitor voltages derivate matrix, $\mathrm{D}$ is the coefficient matrix of $u$ and $u$ is the input sources matrix. $\mathrm{Y}$ as the output signal and can be written as:

$$
Y=v_{o}=\left[\begin{array}{ll}
0 & 1
\end{array}\right]\left[\begin{array}{l}
i_{L} \\
v_{O}
\end{array}\right]
$$

In order to obtain the small-signal model for the boost converter, the equation (11) can be re-written through (14). In this equation, A, B, C and D are the coefficients matrixes and can be introduced for ON and OFF states of power switch: 


$$
\begin{aligned}
& \hat{X}=A \hat{X}+B \hat{u}+\left[\left(A_{1}-A_{2}\right) X+\left(B_{1}-B_{2}\right) u\right] \hat{d} ; \\
& \left\{\begin{array}{l}
A=A_{1} d+A_{2}(1-d) \\
B=B_{1} d+B_{2}(1-d) \\
C=C_{1} d+C_{2}(1-d) \\
D=D_{1} d+D_{2}(1-d)
\end{array}\right.
\end{aligned}
$$

So, we can write:

$$
\left[\begin{array}{c}
\hat{\dot{i_{L 1}}} \\
\hat{\dot{V_{O}}}
\end{array}\right]=\left[\begin{array}{cc}
0 & 0 \\
0 & -\frac{1}{R C}
\end{array}\right]\left[\begin{array}{c}
\hat{i_{l}} \\
\hat{v_{O}}
\end{array}\right]+\left[\begin{array}{c}
\frac{1}{L_{1}} \\
0
\end{array}\right]\left[\begin{array}{l}
\hat{V_{i n}}
\end{array}\right]+\left[\begin{array}{c}
\frac{V_{C}}{L} \\
\frac{I_{L}}{C}
\end{array}\right] \hat{d}
$$

This equation can be expanded by the Laplace equation for the ON and OFF sates as below:

$$
\begin{aligned}
& \left(s+\frac{T R_{L}}{L}\right) I_{L, p}(s)=i_{L 0, p}+\frac{T}{L S} V_{i} \quad \text { if } 0 \leq q<D, \\
& \left(s+\frac{T}{R C}\right) V_{o, p}(s)=v_{o 0, p} \quad \text { if } \quad 0 \leq q<D, \\
& \left(s+\frac{T R_{L}}{L}\right) I_{L, p}(s)=+i_{L 1, p}+\frac{T}{L S} V_{i}-\frac{T}{L} V_{o, p}(s), D \leq q<1, \\
& \left(s+\frac{T}{R C}\right) V_{o, p}(s)=v_{o 1, p}+\frac{T}{C} I_{L, p} \quad \text { if } \quad D \leq q<1,
\end{aligned}
$$

In these equations, $i_{L 0, p}, i_{L 1, p}, v_{00, p}$ and $v_{01, p}$ are the primary values of the inductor current and capacitor voltage signals for the ON and OFF states respectively, $\mathrm{T}$ is the period of PWM signal and $\mathrm{R}_{\mathrm{L}}$ is the internal resistance of the inductor that can be an ignored because it is very small in comparison with the output load normally.

So this primary values can be found in Laplace mode as below:

$$
\left[\begin{array}{l}
I_{L, p}(s) \\
V_{o, p}(s)
\end{array}\right]=\left[\begin{array}{c}
\frac{1}{s+(\alpha-\gamma) T}\left(i_{L 0, p}+\frac{T}{L} \frac{V_{i}}{s}\right) \\
\frac{v_{o 0, p}}{s+(\alpha+\gamma) T}
\end{array}\right] \text { if } 0 \leq q<D
$$

$$
\left[\begin{array}{c}
I_{L, p}(s) \\
V_{o, p}(s)
\end{array}\right]=\frac{1}{s^{2}+2 \alpha T s+T^{2}\left(\alpha^{2}+\omega^{2}\right)} \times\left[\begin{array}{cc}
(\alpha+\gamma) T+s & -\frac{T}{L} \\
\frac{T}{C} & s+T(\alpha-\gamma)
\end{array}\right]\left[\begin{array}{c}
i_{L 1, p}+\frac{T V_{i}}{L s} \\
v_{o 1, p}
\end{array}\right] \text { if } D \leq q<1,
$$

$\alpha, \omega$ and $\gamma$ can be presented below equation: 


$$
\alpha=\frac{\left(\frac{R_{L}}{L}+\frac{1}{R C}\right)}{2}, \quad \omega=\sqrt{\frac{1}{L C}\left(\frac{R_{L}}{R}+1\right)-\alpha^{2}}, \quad \gamma=\frac{\left(\frac{1}{R C}-\frac{R_{L}}{L}\right)}{2},
$$

By applying the conversely Laplace function for the (20) and (21), the input current and capacitor voltage will be obtained as follows in the $q$ domain:

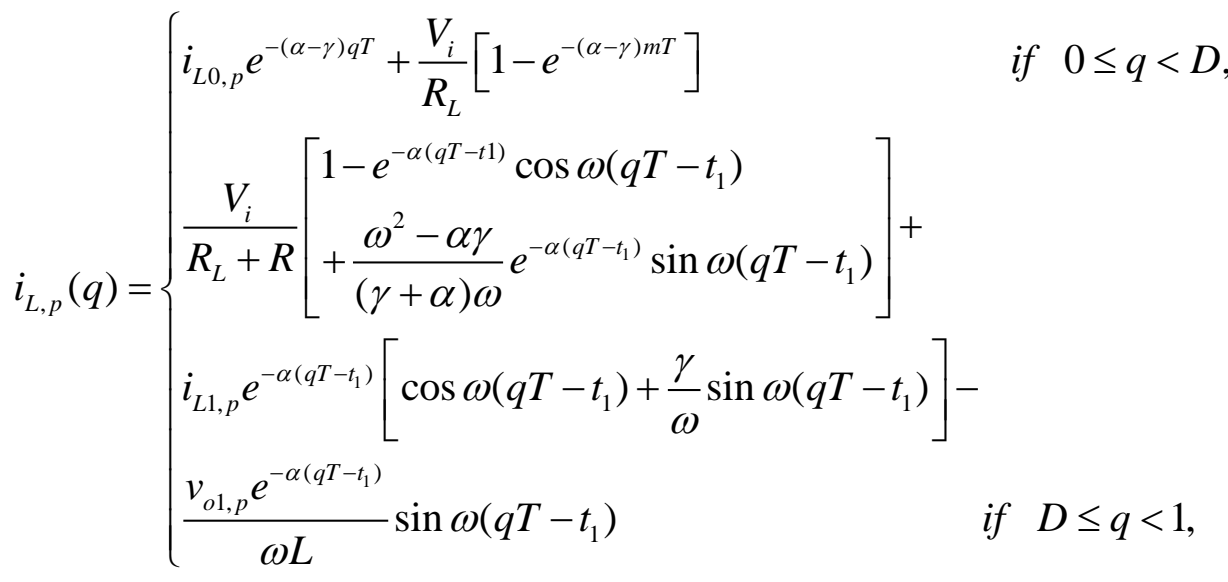

$$
\begin{aligned}
& v_{o, p}(q)= \begin{cases}v_{o 0, p} e^{-(\alpha+\gamma) q T} & \text { if } \quad 0 \leq q<D, \\
\frac{R V_{i}}{R_{L}+R}\left[\begin{array}{c}
1-e^{-\alpha\left(q T-t_{1}\right)} \cos \omega\left(q T-t_{1}\right) \\
-\frac{\alpha}{\omega} e^{\alpha\left(t_{1}-q T\right)} \sin \omega\left(q T-t_{1}\right)
\end{array}\right]+ & \\
\frac{i_{L 1, p} e^{-\alpha\left(q T-t_{1}\right)} \sin \omega\left(q T-t_{1}\right)+v_{o 1, p} e^{\alpha\left(t_{1}-q T\right)}\left[\begin{array}{l}
\cos \omega\left(q T-t_{1}\right)+ \\
\frac{\gamma}{\omega} \sin \omega\left(t_{1}-q T\right)
\end{array}\right] \quad \text { if } \quad D \leq q<1,}{\omega C},\end{cases}
\end{aligned}
$$

\section{Controller design}

Open-loop boost converters cannot guarantee a stable DC voltage on the load side. Especially when the input source is a PV panel, fuel cell or wind turbine, based on geographical and weather conditions, different amount of power can be generated by these sources. Also, when the second, third or higher level of loads enter to the output of the converter, different amount of voltages can be obtained or unwanted amount of over or undershoots can be observed. So, in a DC-DC boost converter, always a closed-loop controller is preferred. For this purpose, in this study we will proposed three different controllers with all mathematical details. For the first step, the PI controller will introduce, and in continuous the Sliding Mode Controller (SMC) and Fuzzy Logic Controller (FLC) will present. The differences between the quality of the generated signals will present in the results section.

\subsection{PI controller}

In order to present a PI controller, the most important fact is finding an equation that can present a connection between output voltage with first order derivation of the inductor current or capacitor voltage. Between all equations from (1) till (11), (5) is the optimal one.

$$
C \frac{d v_{o}}{d t}+\frac{1}{R} v_{o}=(1-d) i_{L}=u
$$

in time domain: $u(t)=K_{p} e(t)+K_{i} \int_{0}^{t} e(\tau) d \tau$ 
$\mathrm{K}_{\mathrm{p}}$ and $\mathrm{K}_{\mathrm{i}}$ are the proportional and integral coefficients. In this equation $\mathrm{u}$ is the control signal at the controller output point and can be introduced in term of duty cycle as below:

$$
d=1-\frac{u}{i_{L}}
$$

Since the PI controller can be present by (26):

$$
G(s)=k_{p}+\frac{k_{i}}{s}=\frac{k_{p} s+k_{i}}{s}
$$

The controller loop and closed loop PI controller form will be same with what is illustrated in figure $4 \mathrm{a}$ and $4 \mathrm{~b}$ respectively.

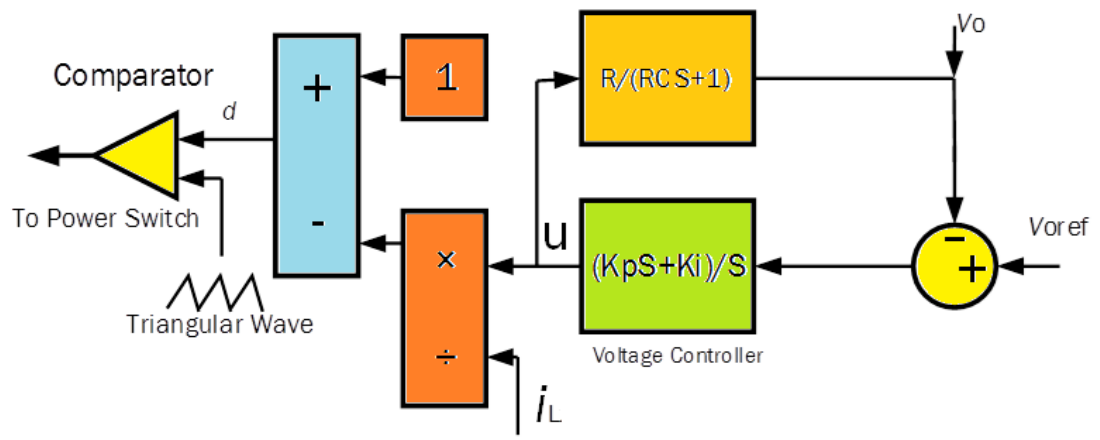

(a)

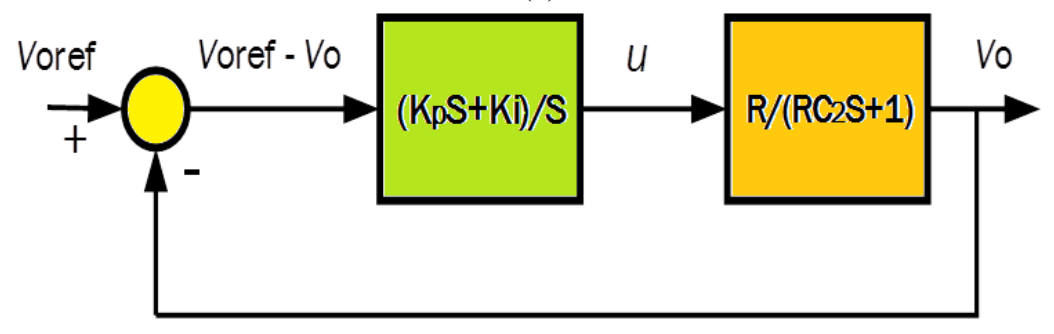

(b)

Figure 4. (a) controller loop and (b) closed loop PI controller model for the step-up converter

By considering the figure $3 \mathrm{~b}$, the transfer function between input and output voltages can be presented by (27):

$$
\begin{aligned}
& G_{F}=\frac{V_{o}(s)}{V_{o_{r e f}}(s)}=\frac{G_{C}(s) G_{P}(s)}{1+G_{C}(s) G_{P}(s)}=\frac{G_{o}}{1+G_{o}}=\frac{\frac{1}{C}\left(k_{p}+k_{i}\right)}{s^{2}+\left(\frac{1+R k_{p}}{R C}\right)+\frac{k_{i}}{C}} \Rightarrow G_{F}=\frac{\frac{1}{C}\left(k_{p} s+k_{i}\right)}{s^{2}+2 \xi \omega_{0} s+\omega_{o}^{2}} \\
& \text { So, }\left\{\begin{array} { r } 
{ \frac { 1 + R k _ { p } } { R C _ { 2 } } = 2 \xi \omega _ { 0 } } \\
{ \frac { k _ { i } } { C _ { 2 } } = \omega _ { 0 } ^ { 2 } }
\end{array} \Rightarrow \left\{\begin{array}{r}
k_{p}=2 \xi \omega_{0} C_{2}-\frac{1}{R} \\
k_{i}=\omega_{0}^{2} C_{2}
\end{array}\right.\right.
\end{aligned}
$$

The effect of the integral control becomes more pronounced when used in conjunction with the proportional control effect. The integral effect is activated at a certain time after the controller is activated. Again, since it is known that the proportional control effect weakens as the error decreases, it can be easily predicted that these two effects can be used as a compliment. The proportional effect will quickly lose the effect after bringing the system response closer to the input value, after which the integral effect will activate and eliminate the permanent error and move the system to the full reference value if it is slow.

\subsection{Sliding mode controller (SMC)}

Sliding mode control is a robust control method that can achieve the desired dynamic behavior despite external disturbances and uncertainties when appropriate conditions are met. The SMC method has become popular in recent years due to its simplicity of application and robustness, and many SMC techniques have been developed and have taken their place in engineering applications. 
However, in the open literature, it is seen that there is no comprehensive study in which these control techniques are applied simultaneously on various real systems.

To implement variable structure control, the steady sate equation for inductor current or capacitor voltage derivations can be written in a general form as below:

$$
\frac{d x}{d t}=A x+B s+G
$$

S presents the switch state; $\mathrm{x}$ is the state vector and representing the state variables; and A, B and G are the state matrices. Since the controller diagram is organized based on the mean state space model, so the model should be created first. Regarding the modeling of the DC-DC step-up converter, the Continuous Conduction Mode (CCM) is considered. State space equations in CCM when the power switch is in on state, $\mathrm{S}=1$, can be illustrated by:

$$
L \frac{d i}{d t}=u_{i} \quad \text { and } \quad C \frac{d v}{d t}=-\frac{u_{0}}{R}
$$

For the time intervals that the switch is in off state, $S=0$ :

$$
L \frac{d i}{d t}=u_{i}-u_{0} \quad \text { and } \quad C \frac{d v}{d t}=i_{L}-\frac{u_{0}}{R}
$$

(31) presents the combination and general state matrix for the converter:

$$
\left[\begin{array}{c}
\frac{d i_{L}}{d t} \\
\frac{d u_{0}}{d t}
\end{array}\right]=\left[\begin{array}{cc}
0 & -\frac{1}{L} \\
\frac{1}{C} & -\frac{1}{R C}
\end{array}\right]\left[\begin{array}{c}
i_{L} \\
u_{0}
\end{array}\right]+\left[\begin{array}{c}
\frac{u_{0}}{L} \\
-i_{L}
\end{array}\right] s+\left[\begin{array}{c}
u_{i} \\
L
\end{array}\right]
$$

According to the shift mode control theory, the proportional shift function of the proposed SMC varies according to the time in the state space,

$$
S_{s}=K_{1}(t) x\left(u_{o e}-u_{o}\right)
$$

where $\mathrm{k} 1(\mathrm{t})>0$ is the sliding coefficient which can be designed as a constant or time variable parameter according to different states of the structure, while it should be appropriately selected to fulfill the condition of existence, the reach/strike and the stability conditions. Since K1(t) is the fixed part during different stable states in this control approach, its derivative is zero in any fixed state. Therefore, the differential shift is expressed by the function (33):

$$
\dot{S}=-K_{1}(t) \dot{u}_{o}
$$

By a similar way as we had for PI controller we can write for SMC (34):

$$
u_{e q}=1-\frac{u_{o}}{R i_{L}}
$$

It is then defined by the relevant trend law by (35):

$$
S_{\text {law }}=-K_{2}(t)\left(u_{o e}-u_{o}\right)
$$

The trend rate can be adjusted by setting the coefficient $\mathrm{k}_{2}(\mathrm{t})>0$. Based on control law for converters in order to general shift mode control purposes, which should be able to control the output of the system by monitoring the reference values of the output signals:

$$
u=\left\{\begin{array}{lll}
u^{+}, & \text {if } & S_{s}>0 \\
u^{-}, & \text {if } & S_{s}<0
\end{array}\right.
$$

By replacing the mean state space model of the system to the control law equation, the dynamic duty cycles for PWM generation can be obtained directly: 


$$
\begin{gathered}
0\left\langle d(t)=1-\frac{k_{1} u_{i}+\sqrt{k_{1}{ }^{2} u_{i}{ }^{2}+k \cdot u_{o}\left(u_{o e}-u_{o}\right)}}{2 k_{1} u_{o}}\langle 1\right. \\
k=\frac{4 L}{R}\left(C R k_{2}{ }^{2}-k_{1} k_{2}\right)
\end{gathered}
$$

Obviously in the ideal condition, when the error between the reference output and the actual output voltage is zero:

$$
d(t)=1-\frac{u_{i}}{u_{o e}}
$$

Figure 5 presents the Simulink model of the SMC controller for the conventional boost converter. Independent of the general control schemes for DC-DC boost converters, (38) is the general steady-state relationship between the input and output voltages. It can be seen that the controller is independent of the inductor current, and the load information is only required when designing the shift coefficients.

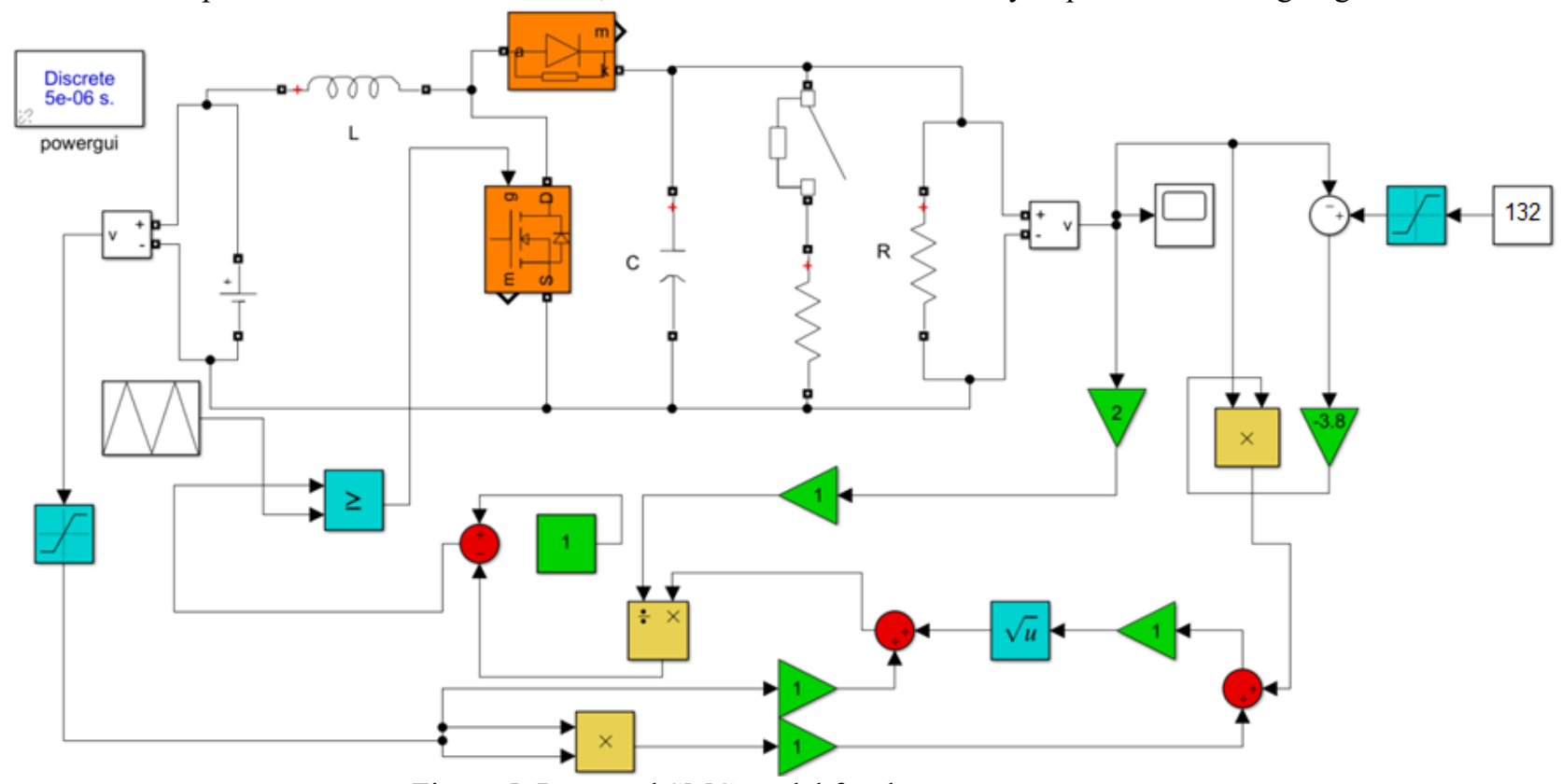

Figure 5. Proposed SMC model for the step-up converter.

According to Lyapunov's theory of stability, the candidate scalar quadratic Lyapunov function is same with (39):

$$
V(x)=\frac{1}{2} e^{T} Q_{e}=\frac{1}{2}\left(x-x_{e}\right)^{T} Q\left(x-x_{e}\right)
$$

Where $\mathrm{x}=\left[\mathrm{i}_{\mathrm{L}} \mathrm{u}_{\mathrm{o}}\right]^{\mathrm{T}}$ is the state variables and $\mathrm{Q}$ is a diagonal matrix:

$$
\begin{aligned}
& V\left(i_{L}, u_{o}\right)=\frac{1}{2}\left[a_{1}\left(i_{L}-i_{e}\right)^{2}+a_{2}\left(u_{o}-u_{e}\right)^{2}\right]=\left[\begin{array}{llll}
a_{1} & 0 ; & 0 & a_{2}
\end{array}\right] \text { for }\left(a_{1}, a_{2}>0\right) \\
& \text { and } V\left(i_{e} u_{e}\right)=0
\end{aligned}
$$

By the derivative state of the V:

$$
\dot{V}=\frac{1}{2} \dot{e}^{T} Q_{e}+\frac{1}{2} e^{T} \dot{Q} \dot{e}=-a_{2} \frac{k_{2}}{k_{1}}\left(u_{o}-u_{e}\right)^{2}+\frac{a_{2}}{L}\left[u_{i}-(1-s) u_{o}\right]\left[i_{L}-\frac{u_{e}^{2}}{R u_{i}}\right]
$$

When $\mathrm{u}_{0}>\mathrm{u}_{\mathrm{e}}$, based on the energy saving theory, the losses are ignored and $\left[\mathrm{u}_{\mathrm{i}}-(1-\mathrm{S}) \mathrm{u}_{\mathrm{o}}\right]<0$ in the next stage. This results in $\mathrm{i}_{\mathrm{L}}>\mathrm{i}_{\mathrm{e}}$, so $\left[\mathrm{i}_{\mathrm{L}}-\left(\mathrm{u}_{\mathrm{e}}^{2} / \mathrm{Ru}_{\mathrm{i}}\right)\right]>0$ and by $\mathrm{u}_{0}<\mathrm{u}_{\mathrm{e}},\left[\mathrm{u}_{\mathrm{i}}-(1-\mathrm{s}) \mathrm{u}_{\mathrm{o}}\right]<0,\left[\mathrm{i}_{\mathrm{L}}-\left(\mathrm{u}_{\mathrm{e}}{ }^{2} / \mathrm{Ru}_{\mathrm{i}}\right)\right]<0$.

In summary, for any $\mathrm{x} \neq \mathrm{xe}(41)$ will be negative and when $\mathrm{x}=\mathrm{xe}$ is zero, therefore the response is negative certainly. As a result, the candidate function is a Lyapunov function and the system complies with Lyapunov stability conditions. The system is therefore asymptotically stable at equilibrium points.

When the system is balanced at equilibrium, the output and input powers are equalized by examining the energy conservation law and neglecting the lost energy: 


$$
P_{\text {in }}=u_{i} i_{e}=P_{\text {out }}=\frac{u_{e}^{2}}{R}
$$

\section{Results and discussions}

The schematic design has is organized with an input voltage of $48 \mathrm{~V}$ and an output voltage of $132 \mathrm{~V}$. The parameters for prototype design were $\mathrm{C}=220 \mu \mathrm{F}, \mathrm{L}=140 \mu \mathrm{H}, \mathrm{R}=500 \Omega$ (load resistance). The power converter switching frequency is selected as $50 \mathrm{kHz}$. All facts about the parameter values can be found in [21]. Different load values applied to test each controller performance and the graphs were compared. The steady-state of the system is determined as the output voltage Vo \pm error margin $(132 \mathrm{~V} \pm 2 \mathrm{~V})$. for both prototypes, we considered two different loads that will apply in different times to analyze the performance of the controllers. Boost converter at the beginning point will start with a $500 \Omega$ resistive load and at the $t=0.75 \mathrm{sec}$, the second load with the same value will enter to the load side. It is an important criterion to test the stability of the controllers to ensure that the output voltage at the second load connection time conditions is not exceeded the desired ranges. Ideally, no overshoot or undershoot is the desired criteria for a good controller. Figure $6 \mathrm{a}$ presents the performance of the controllers in start and load changing times. As can be seen, for the start point, SMC has a higher overshoot value but the settling time to reach to the fixed 132 VDC is shorter for this controller, instead PI controller has an optimal overshoot and damping conditions but the settling time is longer for this controller. As mentioned above, the second load is applied at the $\mathrm{t}=0.75 \mathrm{sec}$. SMC controller seems have a better performance for load sharing problem since a voltage droop equal with 1 VDC will occur at the output point of the converter by this controller but an overshoot for the PI controller will appear. Figures $6 \mathrm{~b}$ and $6 \mathrm{c}$ show this states with all details.

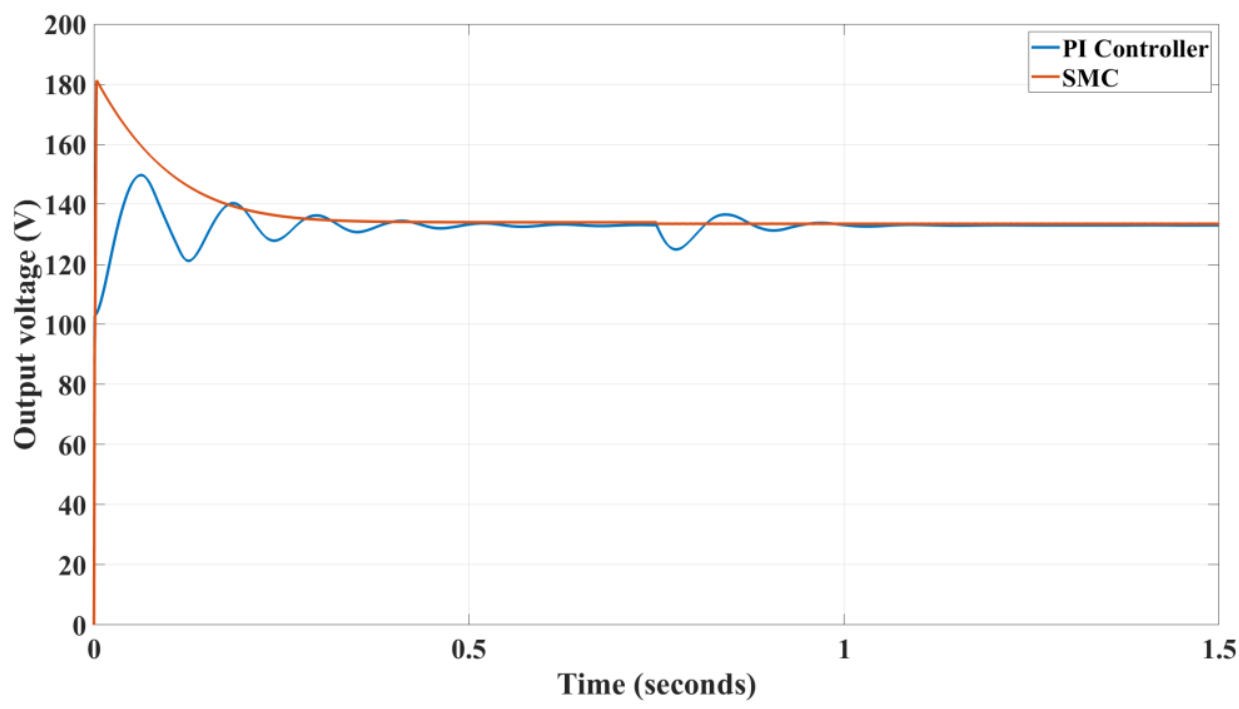

(a)

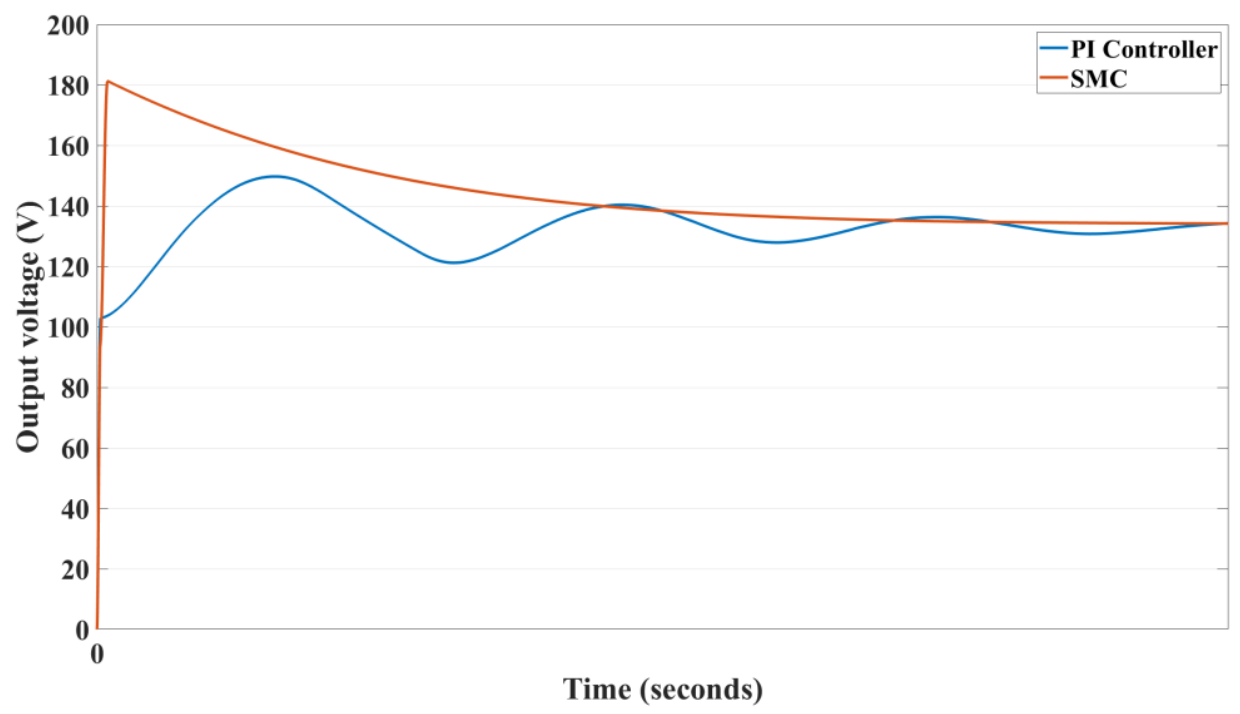

(b) 


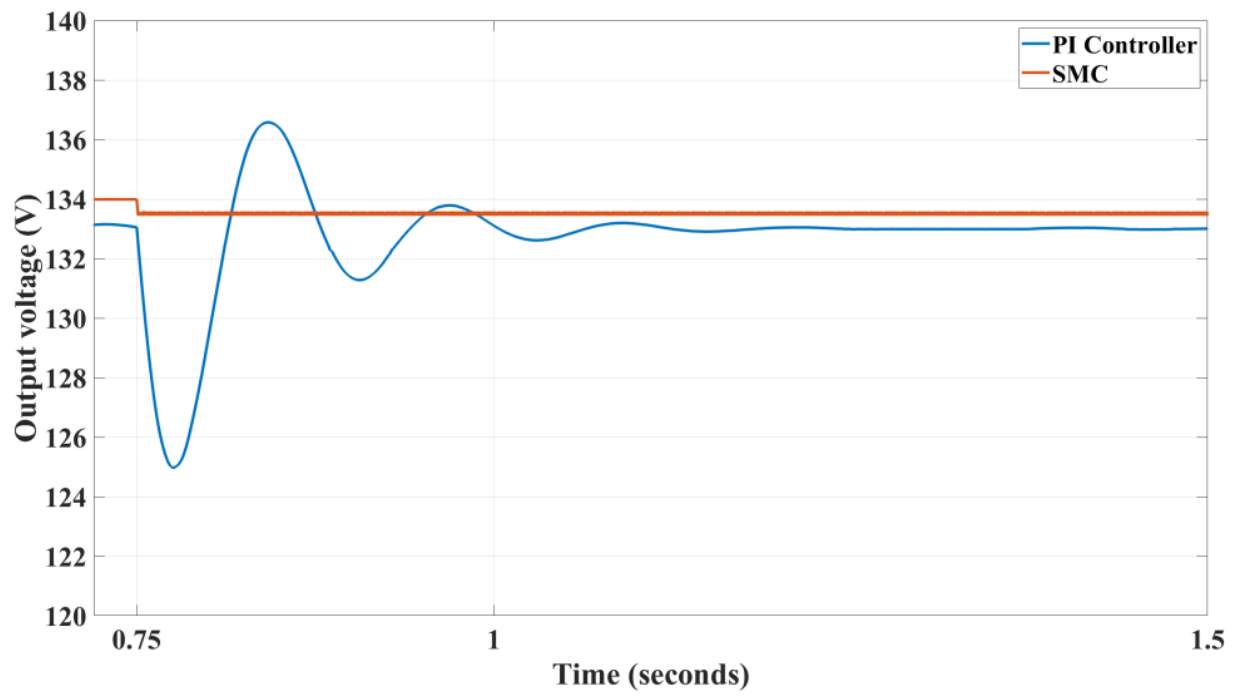

(c)

Figure 6. (a) General comparison for PI and SMC performances, and zoomed on (b) start point and (c) load changing time.

Reliability analysis including the current measurements for the inductors and power switches are important issues that can guarantee the long life of the structures since these converters should be work for weeks or months by connection to a PV panel or any other renewable energy sources. Figures $7 \mathrm{a}$ and $7 \mathrm{~b}$ illustrate the inductors currents before and after the load changing respectively. For around $50 \mathrm{~W}$ of output power, with approximately the same average current values, the waveform of the current for SMC method is better and PI controller passes a dense current $t$ the points that current reaches to zero. For $100 \mathrm{~W}$ tests, when the second load applied to the output side, the average current for both controllers enhance normally but the mentioned problem for the PI method has remained. This can be seen through figure $7 \mathrm{~b}$. also figure 8 presents the current waveforms of the power switch and the same problem seems for this current. So, in order to supply the working security and stability for the power switches SMC can show a better role. Figures $8 \mathrm{a}$ and $8 \mathrm{~b}$ present these currents before and after load changing point.

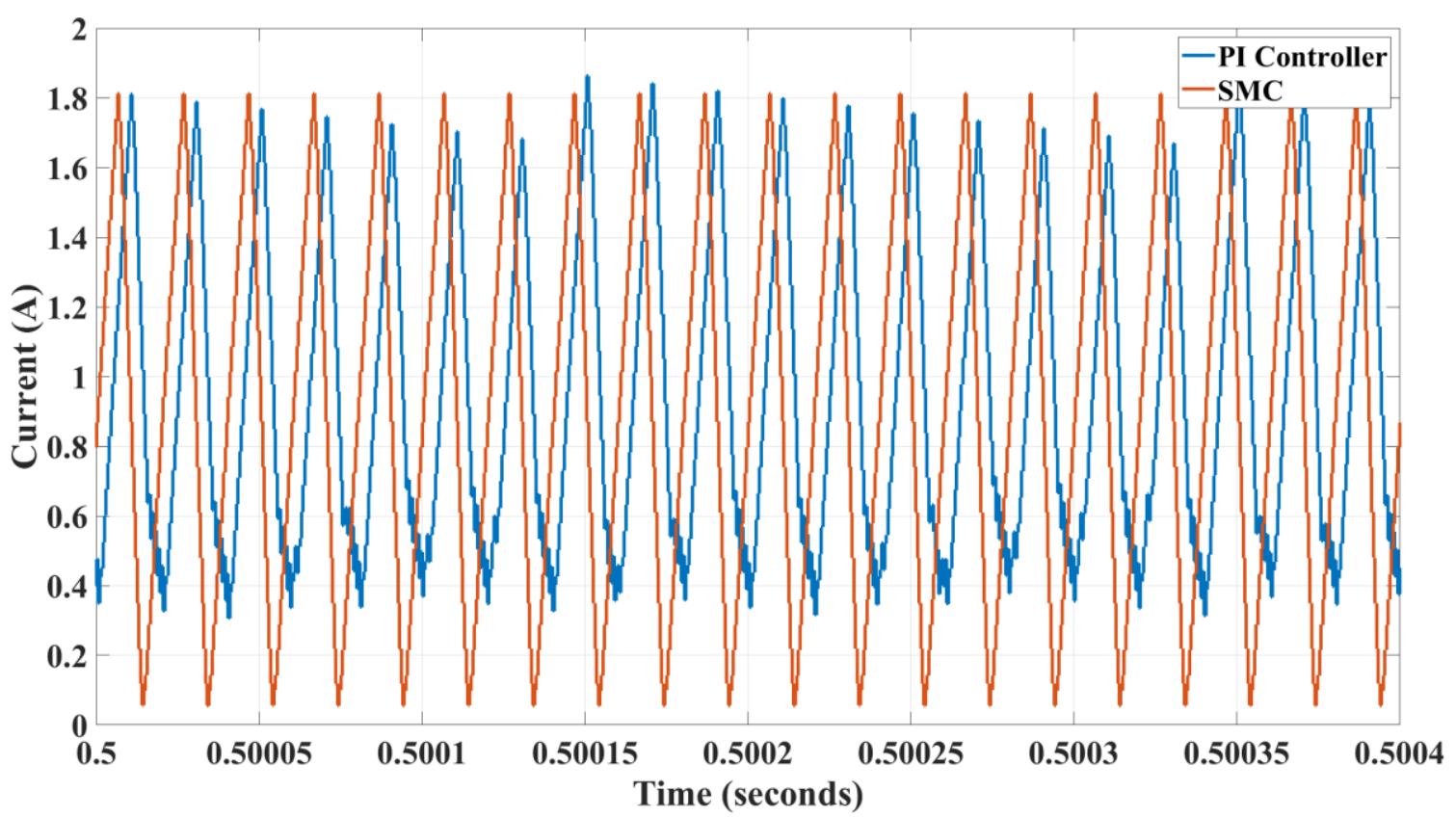

(a) 


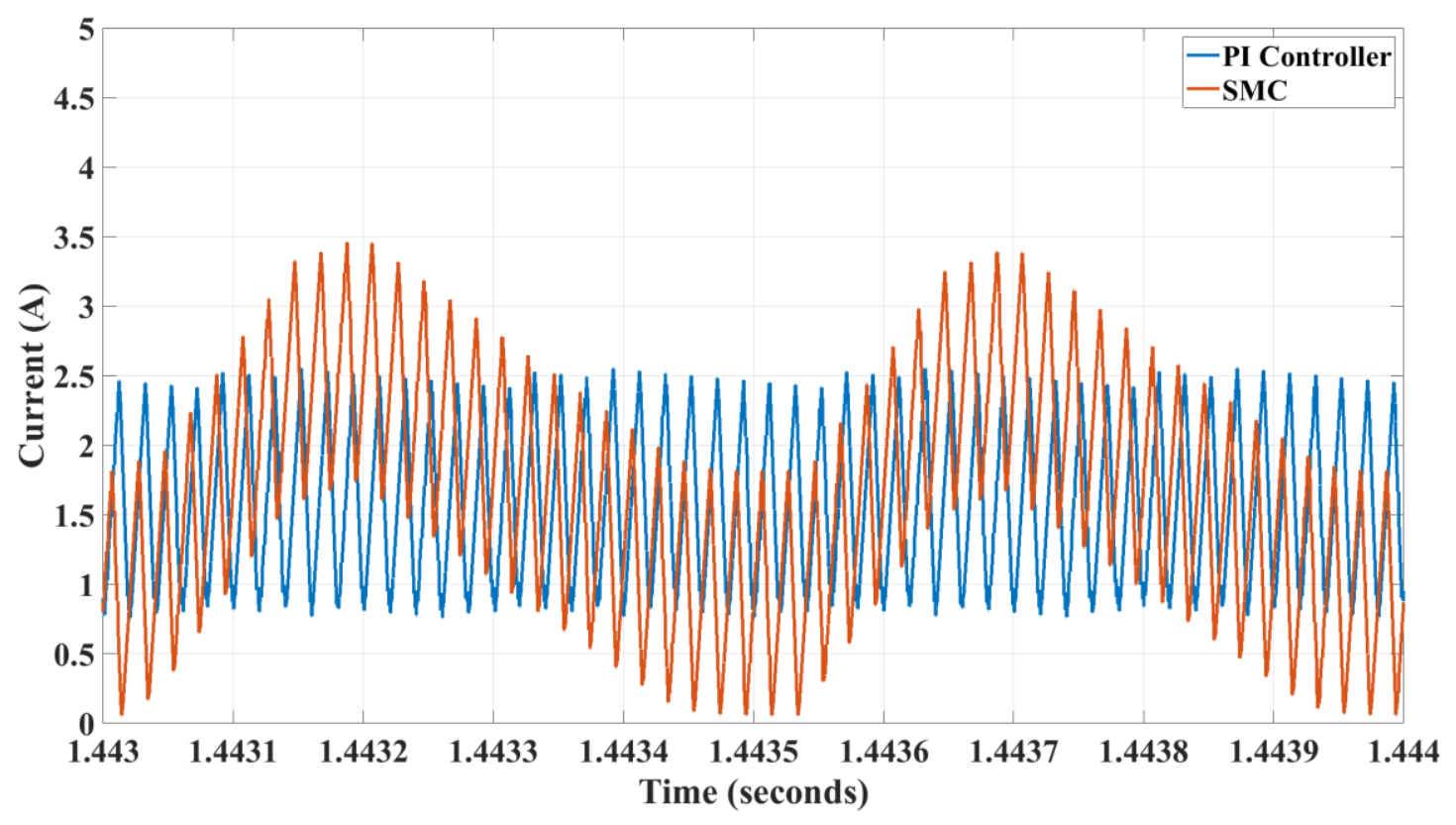

(b)

Figure 7. Inductor current with PI and SMC methods when output power is around (a) $50 \mathrm{~W}$ and (b) $100 \mathrm{~W}$.

Figure 9 presents the output current of the converter by these controllers at the load changing point. Although the PI controller after a short fluctuation reaches to the new level of the current, the SMC controller shows a better performance for this state and with a sharp rise and doubles the current by considering two same values of the loads.

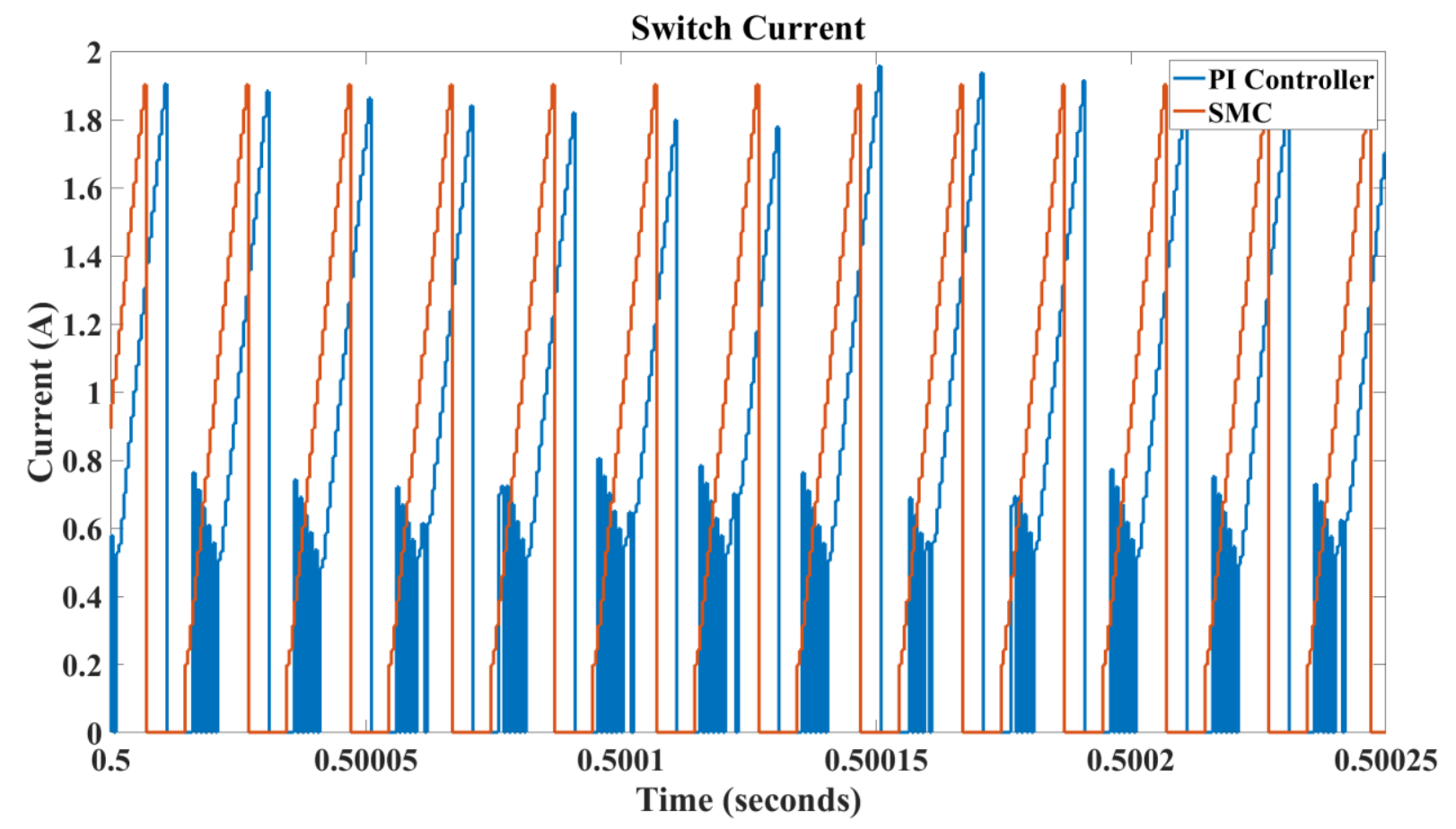

(a) 


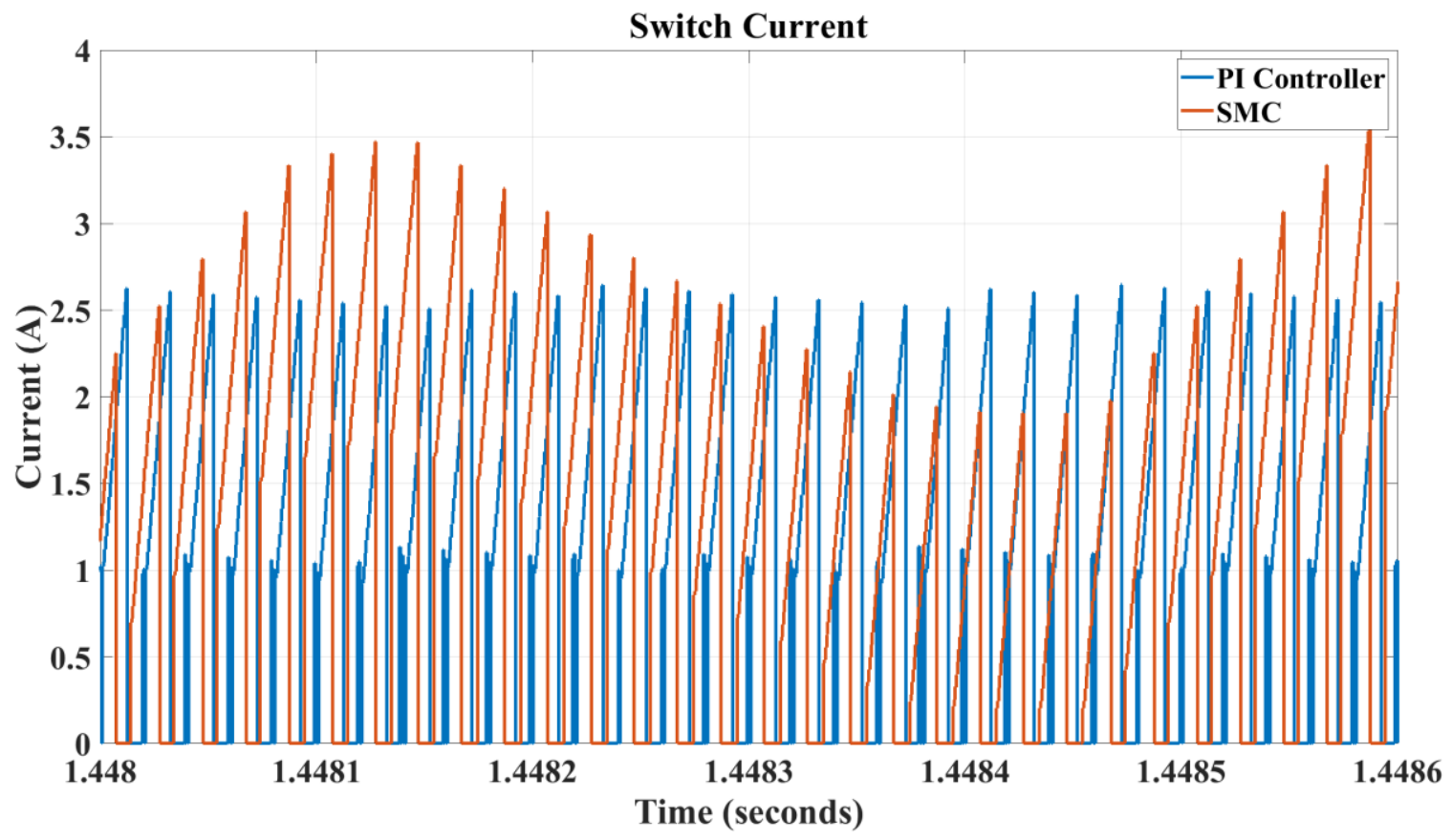

(b)

Figure 8. Switch current with PI and SMC methods when output power is around (a) 50W and (b) $100 \mathrm{~W}$.

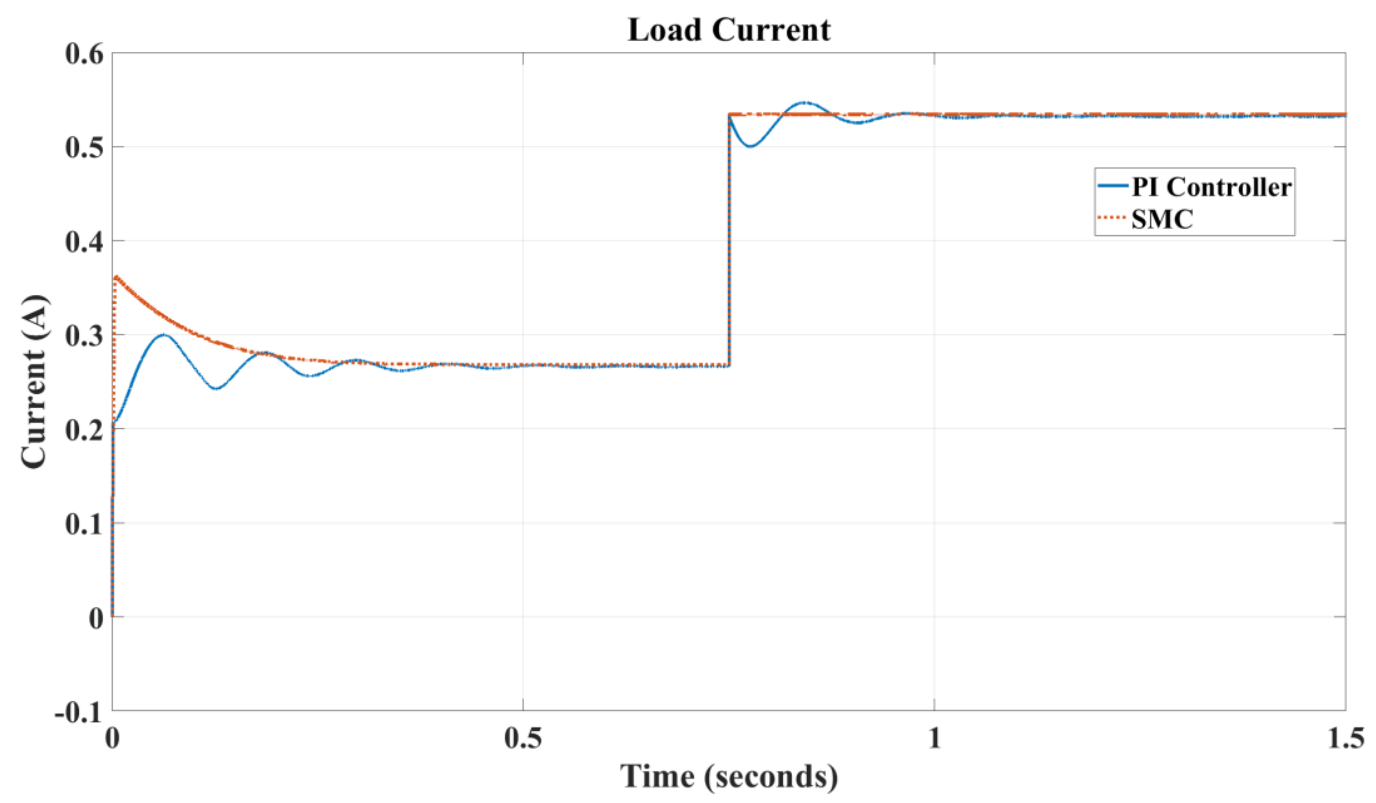

Figure 9. Output current waveforms through the PI and the SMC controller methods.

\section{Conclusion}

In this study two different PI and SMC methods in order to control and fix the output voltage of a step-up converter presented. For presenting the controller models, in the first step, the mathematical analysis of the converter with a novel space state matrices model presented. The Laplace and inverse Laplace models presented to find the output voltage and input current of the boost converter. In the next step and based on results of the mathematical analysis of the boost converter, two PI and SMC methods introduces to fix the output voltage under the different load values. One of novelty aspects of the PI controller is that it will give sample currents of the inductor to make a relation between the output voltage and the controller strategy in order to generate suitable pulses to drive the power switch and SMC does not need to any sampling for this purpose and acts through tracking the output voltage. For both models, a wide range of equations presented and according to the simulation results, the SMC method showed a better performance. Especially at the start point of the converter, although a higher overshoot for the SMC reported but the damping of this model is les and reaches and tracks the desired voltage at the output side quicker. Also, by changing the load values, the oscillation of the output voltage is lees for SMC, while higher voltage fluctuations reported for PI method. Current waveforms for the inductor and power switch show that reliability of the 
SMC model acts stronger in comparison with PI method. So we can result, although PI controller has closed to zero steady state error, but the maximum peak and overshoot or undershoot of this controller is better that I (integral) controller and not better than SMC. This results in not using of PI for slow moving variables processes but it can applicable in motor, generator and turbines speed control process. The basic of the SMC, is a roust control model in order to control the system with uncertainties. The problem of establishing control systems with static and dynamic properties closed to optimal ones according to the determined effectiveness criteria becomes urgent under the conditions of limited access to measurement information and lack of initial information about the control object's properties, which is typical for many technical applications.

\section{References}

[1.] Jiang, W., Chincholkar, S. H., and Chan, C. (2018). Investigation of a Voltage-Mode Controller for a dc-dc Multilevel Boost Converter, IEEE Transactions on Circuits and Systems II: Express Briefs, 65, 908-912.

[2.] Sundareswaran, K., and Sreedevi, V. T. (2018) Boost Converter Controller Design Using Queen-Bee-Assisted GA, IEEE Transactions on Industrial Electronics, 56, 778-783.

[3.] Rana, N., Ghosh, A., and Banerjee, S. (2017). Development of an Improved Tristate Buck-Boost Converter with Optimized Type3 Controller, IEEE Journal of Emerging and Selected Topics in Power Electronics, 6, 400-415.

[4.] Veerachary, M., and Shaw, P. Controller Design and Analysis for Fifth-Order Boost Converter, IEEE Transactions on Industry Applications, 54, 4894-4907.

[5.] Marcillo K. E. L. (2019). Interval Robust Controller to Minimize Oscillations Effects Caused by Constant Power Load in a DC Multi-Converter Buck-Buck System, IEEE Access, 7, 26324-26342.

[6.] Hwu, K. I., and Peng, T. J. (2012). A Novel Buck-Boost Converter Combining KY and Buck Converters, IEEE Transactions on Power Electronics, 27, 2236-2241.

[7.] Wu, H., Mu, T., Ge, H., and Xing, Y. (2016). Full-Range Soft-Switching-Isolated Buck-Boost Converters with Integrated Interleaved Boost Converter and Phase-Shifted Control," in IEEE Transactions on Power Electronics, 31, 987-999.

[8.] H. Liu, Y. Ji, L. Wang and P. Wheeler, "A Family of Improved Magnetically Coupled Impedance Network Boost DC-DC Converters," in IEEE Transactions on Power Electronics, vol. 33, no. 5, pp. 3697-3702, May 2018. doi: 10.1109/TPEL.2017.2763153

[9.] Ghaderi, D., Çelebi, M., Minaz, M. R., Tören, M. (2018). Efficiency Improvement for a DC-DC Quadratic Power Boost Converter by Applying a Switch Turn-off Lossless Snubber Structure Based on Zero Voltage Switching, in Elektronika ir Elektronicha, vol. 24 no. 3, doi: https://doi.org/10.5755/j01.eie.24.3.20977.

[10.] Rana, N., Kumar, M., Ghosh, A., and Banerjee, S. (2018) A Novel Interleaved Tri-State Boost Converter with Lower Ripple and Improved Dynamic Response," in IEEE Transactions on Industrial Electronics, 65, 5456-5465.

[11.] Forouzesh, M., Siwakoti, Y. P., Gorji, S. A., Blaabjerg, F., and Lehman, B. (2017). Step-Up DC-DC Converters: A Comprehensive Review of Voltage-Boosting Techniques, Topologies, and Applications, IEEE Transactions on Power Electronics, 32, 9143-9178.

[12.] Pandey, S. K., Patil, S. L., Phadke, S. B. (2018). Comment on "PWM-Based Adaptive Sliding-Mode Control for Boost DCDC Converters, IEEE Transactions on Industrial Electronics, 65, 5078-5080.

[13.] Lee, S., Do, H. (2018). High Step-Up Coupled-Inductor Cascade Boost DC-DC Converter with Lossless Passive Snubber, IEEE Transactions on Industrial Electronics, 65, 7753-7761.

[14.] Kim, J., Choi, H., Won, C. (2018). New Modulated Carrier Controlled PFC Boost Converter, IEEE Transactions on Power Electronics, 33, 4772-4782.

[15.] Kim, I. H., and Son, Y. I. (2017). Regulation of a DC/DC Boost Converter Under Parametric Uncertainty and Input Voltage Variation Using Nested Reduced-Order PI Observers, IEEE Transactions on Industrial Electronics, 64, 552-562.

[16.] Genc, N., Uzmus, H., and Iskender, I. (2016). Dynamic behavior of dc-dc boost converter controlled with cascade PI-ASC, 2016 8th International Conference on Electronics, Computers and Artificial Intelligence (ECAI), Ploiesti, 1-4.

[17.] Rabiaa, O., Mouna, B. H., Lassaad, S., Aymen, F., and Aicha, A. (2018). Cascade Control Loop of DC-DC Boost Converter Using PI Controller, 2018 International Symposium on Advanced Electrical and Communication Technologies (ISAECT), Rabat, Morocco, 2018, pp. 1-5.

[18.] Mohanty, P. R. and Panda, A. K. (2017). Fixed-Frequency Sliding-Mode Control Scheme Based on Current Control Manifold for Improved Dynamic Performance of Boost PFC Converter, IEEE Journal of Emerging and Selected Topics in Power Electronics, $5,576-586$.

[19.] Chincholkar, S. H., Jiang, W., and Chan, C. (2018). A Modified Hysteresis-Modulation-Based Sliding Mode Control for Improved Performance in Hybrid DC-DC Boost Converter, IEEE Transactions on Circuits and Systems II: Express Briefs, 65, 1683-1687.

[20.] Mokhtar, M., Marei, M. I., and El-Sattar, A. A. (2019). An Adaptive Droop Control Scheme for DC Microgrids Integrating Sliding Mode Voltage and Current Controlled Boost Converters, IEEE Transactions on Smart Grid, 10, 1685-1693.

[21.] Ghaderi, D., Bayrak, G. (2019). A Novel Step-Up Power Converter Configuration for Solar Energy Application, Elektronika ir Elektronicha, 25, 50-55. 